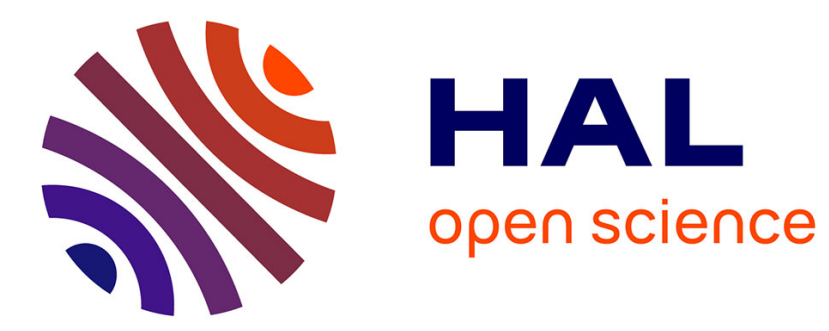

\title{
INTRODUCTION. THE CONTROVERSIAL ECONOMIC QUESTION OF PEACE AND WAR
}

Jacques Fontanel, Manas Chatterji

\section{To cite this version:}

Jacques Fontanel, Manas Chatterji. INTRODUCTION. THE CONTROVERSIAL ECONOMIC QUESTION OF PEACE AND WAR. Jacques Fontanel \& Manas Chatterji. War, Peace and security, Emerald, 2009. hal-03173619

\section{HAL Id: hal-03173619 https://hal.univ-grenoble-alpes.fr/hal-03173619}

Submitted on 18 Mar 2021

HAL is a multi-disciplinary open access archive for the deposit and dissemination of scientific research documents, whether they are published or not. The documents may come from teaching and research institutions in France or abroad, or from public or private research centers.
L'archive ouverte pluridisciplinaire HAL, est destinée au dépôt et à la diffusion de documents scientifiques de niveau recherche, publiés ou non, émanant des établissements d'enseignement et de recherche français ou étrangers, des laboratoires publics ou privés. 


\title{
INTRODUCTION \\ THE CONTROVERSIAL ECONOMIC QUESTION OF PEACE AND WAR \\ Jacques Fontanel \& Manas Chatterji
}

\author{
War, Peace and security, \\ Fontanel, J, Chatterji, M, Eds \\ Emerald, London.
}

\begin{abstract}
Résumé : Economic analyses of peace and war are controversial. Economic theories on the violence of economic factors are heterogeneous. The economy is a factor and an instrument of war, but with the process of globalisation, many economists consider that economic knowledge becomes a factor of peace. It is therefore interesting to analyse the influence of economic powers of nations on the effects of domination and global conflicts, the influence of economic variables on human security, the determinants of military expenditure, the economic impact of terrorism, the economic reorganisation of the military sector, the industrial establishment of defence in Russia, the evolution and future of European defence companies, peacekeeping operations, humanitarian actions and sustainable development, economic intelligence, the economic consequences of the environment, and the approach to conflicts by race and gender.
\end{abstract}

Les analyses économiques sur la paix et la guerre sont controversées. Les théories économiques sur la violence des facteurs économiques sont hétérogènes. L'économie est un facteur et un instrument de guerre, mais avec le processus de globalisation, beaucoup d'économistes considèrent que la connaissance économique devient un facteur de paix. Il est alors intéressant d'analyser l'influence des puissances économiques des nations sur les effets de domination et les conflits globaux, l'influence des variables économiques sur la sécurité humaine, les déterminants des dépenses militaires, l'impact économique du terrorisme, la réorganisation économique du secteur militaire, l'implantation industrielle de la défense en Russie, l'évolution et l'avenir des entreprises de défense européennes, les opérations de maintien de la paix, les actions humanitaires et le développement durable, l'intelligence économique, les conséquences économiques de l'environnement, et l'approche des conflits par la race et le genre.

Mots clés ; Peace, War, economic globalization, economic development, States power, military expenditures, arms race

Paix, guerre, mondialisation économique, développement économique, puissance des États, dépenses militaires, course aux armements 
The economists are not always interested by the scientific research of wars and peace, as if it was phenomena was not clearly relevant to economic analysis. Their questions are mainly concerned by the fundamental questions they have always try to answer, such as the dilemma between guns and butter, the bang for a buck and the optimal level of spending. Normally, they use the current hypothesis of a normal situation of peace. However, the main economists had an analysis of war and peace (I). Today, new analyses are developed, but the same kind of doctrines seems to be maintained in their oppositions, by other means and other research methods (II). This book has the ambition to propose new economic analyses about defence and security in order to summarize the "inventory" of modern economic knowledge.

\section{THE MAIN ECONOMIC THOUGHTS ABOUT PEACE AND WARS}

There are three main doctrines about the relation between war and national economy. The first considered that economy based on the market is a cause of war. The second one established that market and economic knowledge are essential for the realization of peace.

\section{Economy as a factor and as an instrument of war}

For some economists, economy is a factor, an objective and an instrument of war. For mercantilists, the power of the Prince is the basic objective of all national economy. Therefore, a cosmopolitan economy has no sense, because the State's power is the main issue, and not the consumer's welfare. War encourages national feeling and, if victorious, it enriches the State. These ideas were to be taken up again partially by List (1840), an advocate of the national system of political economy, who suggests that when the "natural boundaries" of States are not still established, liberal "laissez-faire" leads to the domination of the strongest and that nations must protect themselves against foreign domination. For the German historic school, economic power often leads to political power. Nations have always been organized vertically in a hierarchical and pyramidal division of labour. Economics is not a matter of good or wrong, it is a matter of strong or weak, there is no code of honour, and protectionism is certainly not a sin.

For Marx and Engels, peace and market have no intrinsic moral virtue. War and conflicts relate to the superstructure and are conditioned by antagonistic social relations. Capitalism is a factor of war between social classes. Rosa Luxembourg considered military investment to be very useful for the development of capitalist economies, in the first instance as a catalyst of primitive accumulation; then as an 
instrument of colonial domination; and lastly as a hegemonic factor of the struggle between the capitalist countries to divide up the world. Lenin also thought that imperialism, the highest stage of capitalism, necessarily stigmatized by total wars and the capitalist exploitation of the world, ruled out any non-economic disarmament process without the advent of socialism.

In the same way, Baran and Sweezy argued that military expenditure serves to absorb the economic surplus that monopoly capitalism creates; on that view the arms race matches the logic of capitalism, which seeks to maintain a constant ratio between production and solvent demand through unproductive expenditure. Other analyses went to the same direction, notably those of J.K. Galbraith, who agreed with the idea that the American economy needs armament support in order to maintain its hegemony. Today, the economic importance of the military sector in capitalist economies seems today indisputable; it would be compared to the role played by the military research and development in the development of the ultramodern technologies.

For Jacques Attali even regards war as an extreme manifestation of industrial competition, the creation of demand and the employment of the factors of production. Conflict provides a stimulus to production and transforms the patterns of consumption and social habits. Thinking along the same lines, Marc Guillaume distinguished the code of capital and the code of power; the former demonstrates the social significance of commodities as the main basis of their value; the inequalities that this occasions lead to a continuous struggle against scarcity and have the inevitable result of maintaining class demarcations in a highly oppressive capitalist system. The code of power, on the other hand, is built up from the bureaucratic hierarchy and the monopoly of knowledge, and is the will for power. If civil war is developed in the code of capital, international war is written into the code of power. Military force is an important instrument in the redistribution of consumer rights between countries.

\section{Economic knowledge as a factor of peace}

For the classical British economists, except Malthus, war and preparation for war are mainly political phenomena determined by the monopoly spirit. They condemn the mercantilism thought dominated by the hegemonic drive of the ruler. But for Smith, the art of war is the noblest of arts, and he approves tariffs that would keep defence-related industries strong. Defence is of much more importance than opulence. For Ricardo, armed forces must be established to ensure the States' sovereignty, threatened by less developed economies. Then, the disarmament process of rich countries is dangerous, having regard to the covetousness of their neighbours. For the classical British economists, generalized development thanks to 
industrialization and the diffusion of the market system precedes disarmament. These ideas were to be picked up by Jean-Baptiste Say.

Generally speaking, the neo-classic thought is not mainly concerned by the problems of armament and disarmament. If for Walras, the field of study of the economics throws the national defence back, the universal search for peace underlies its entire scientific project. The economic theory has to lead to the refusal of the wars, what constitutes an objective for the generations to come, thanks to the free trade. For Bhagwati, the globalization process, based on free trade and "laissez-faire", means the disappearing of the economic role of the States. The national defence is not presumed to be developed on the basis of economic interests. The international trade is good for all countries, with the exercise of comparative advantages. There is a horizontal relationship among countries, and not a hierarchical one. There is no national interest beyond the welfare of the individual consumers. Capitalism produces peace.

\section{THE NEW ECONOMIC ANALYSES OR POLICIES OF WAR INSIDE THE ECONOMISTS FOR PEACE AND SECURITY ASSOCIATION}

Three main analyses of war were developed during this last half century: the arms race models, the analysis of economic arms and the development of the exchange of ideas about war and peace by Economists for Peace and Security.

\section{The failure of arms race models}

The arms race can define itself as a dynamic process of interaction and competitive increase of the quantity andlor the quality of armaments by two or several States (or coalition of States) The model of Richardson (1960), established by three equations representing respectively the political factor, the strategic factor and the economic factor, constitutes the basic model. It introduced the military expenditures of the enemy or the enemies, the economic burden (the effect of fatigability) and the grievances. Brito and Intriligator developed this model, introducing more complexity. However several critics of these approaches carried on insufficient taken into account of the internal determiners of military expenditures. First, the econometric tests did not generally allow to validate the hypothesis of a determination of the level of the budgets of defence by the mutual stimulation of the rival or enemy States. In contrary, Seymour Melman ${ }^{1}$ and J.K. Galbraith stressed the national auto stimulation. Second, these models were not

\footnotetext{
${ }^{1}$ Melman, S. (1974), The permanent war economy, American capitalism in decline, Simon and Schuster, New York.
} 
able of putting in evidence the crisis of Soviet Union, because the definition of the threshold of the fatigability is not easy to determine. Finally, they emphasize economic considerations, forgetting to specify the structural characteristics of the studied States.

\section{The concept of economic war}

The concept of economic wars is developed, from Hirschman and Schelling to Baldwin and Gilpin. Several formalized models have also analysed the link between the conflicts and the intensity of trade relations between nations (S.W. Polachek, J.E. Roemer). The neo-mercantilist analysis is not based on precise theoretical foundations. The national security may be threatened by an arms race, by international military and economic domination, but also by indirect strategies of dissuasion and economic forms of retaliation, such as embargoes and boycotts. With a declaration of intention from States, economic factors become weapons.

The use of the economic weapon may generate various strategies.

- Impoverishment resulting from the strain of preparing for war is probably a basic reason for the collapse of the Soviet economy. The development of military expenditure becomes an economic burden for the poorless country. Under these conditions, a State seeks supremacy by indirect means, not so as to gain short-term military supremacy, but so as to weaken the enemy to the point of its economic destabilization.

- For the breaking off strategy, the aim is to create economic problems in the rival country so as to increase its political and social difficulties. Flows of trade and finance are broken off in the attempt to destabilize a country unilaterally exposed to such a decision. An embargo is an instrument of reprisal or deterrence capable of changing the behaviour of the potential enemy, but it is a weapon that is dangerous to the user, because prolonged interruption of trade flows may lead to a permanent loss of markets.

- The aim of the containment strategy is to develop ties of economic interdependence capable of ensuring peace. The Ostpolitik considered that commercial ties had a moderating role on ideologies.

- The aim of the strategy of political violence is to take economic power when it is hostile and progressively to weaken the dominant social groupings. The political forces of the machinery of State and the trade unions must be brought under control to that end.

- The strategy of domination leads the dominant countries to influence the military and strategic decisions of the countries that they dominate. This permits both to create dependence and then to have a political influence and to improve their terms of trade and their global strategic situation. 
In that case, the economy is no longer the quest for material well-being, but one of the means of ensuring social domination. The economic war is difficult to manage. There are always only losers and no winners.

\section{The heterogeneity of the economic analysis in the Association Economists for Peace and Security}

Inside the same international association, it is possible to have more than an economic analysis of peace and wars.

1) At first, there is a basic hypothesis, in conformity with the liberal values; peace is the normal situation of the market economy. Then, the improvement of the knowledge of the economics favours simultaneously the economic development and the disarmament. For the upholders of the theory of the globalization (as Jeffrey Sachs or Robert Solow), the increasing economic interdependences tend to reduce the intervention of authorities in the economy. In this logic, the politic area should be reduced gradually in front of the economic imperatives. Economic knowledge in favour of the market is the best friend of peace. Finally, the international economy underwent irreversible national structural alterations, which are in favour of peace conditions.

2) The Marxist thought transposes the analysis of the class struggle into the international level, making of this situation the explanation of the international conflicts, whatever is their nature. The arms race is a factor of national cohesion in order to hide the inherent inequalities produce by the market economies. For Claude Serfati, it is also an important factor of the hegemony of the most developed countries, in particular in favour of the United States. For heterodox American thought, war or threat of war are useful for the development of the capitalist system (John Kenneth Galbraith).

3) For Reich, according to the policy of Bill Clinton, a country must be driven as a company, in its relations of concurrence and competition. The inevitable destruction of the coherence of the national economies in favour of globalization produces the risks to increase the world insecurity and the growth of impoverishment. For Ann Markusen, by an adapted industrial policy, the United States are intended to be the only referee of an economy henceforth global, within the framework of an international "controlled" peace. In this perspective, States try to promote their appropriate interests on the world scene, but the example of the American society, based on democracy and freedom, constitutes an example and a factor of international peace.

4) War is a consequence of the domination of the rich. A lot of economists, notably those specialized on the developing countries (as Amartya Sen) or on 
former socialist economies (as Stanislav Menschikov), dispute this last position. For them, globalization may be a factor of conflict. It is often (but not only) the economic expression of the domination of the rich countries to the detriment of the poorest and the outcasts. Besides, the sanctions intended to provoke important economic damages for a country, so that it changes its national politics (such as apartheid, violation of the rights of minorities, tyrannies etc.), constitute indisputable power instruments. The ideology of the globalization by the market is the revealing of the dominant thought, the objective of which is the preservation, without pressure, of the Western hegemony. In this case, economic thought is only an argument to preserve the acquired advantages

5) The conquest of markets substitutes itself, at least partially, for the territorial invasion. It is about a permanent war, engaged by nations and their companies, with the aim of a more favourable division of the world production and richness in favour of the national interests. The constant search for "monopolies" is destructive weapons. In this system, the competition is not only military but also mainly economic (Jacques Fontanel). It is then impossible to separate the objectives of economic and military security.

6) The flourish of the institutionnalist and historic analyses established the fact that there are not one but several types of capitalisms, more or less well adapted to the economic war. For Jean-Paul Hébert, today the links between the economic and military branches play an essential role for the national economic power, but it is the countries that perceive the stakes in the " economic war " which are the best placed in the international economic competition. The analyses on the various forms of capitalism remain fruitful to explain the evolution of the international competition and the reorganization of the international economic relations, according to more or less conflicting modes (Douglas North). The question which arises is to know if it is necessary to develop international public goods (Jurgen Brauer), notably that of the world security, by the progressive reduction of military expenditures (Lloyd Dumas). For Roland de Penanros, the disarmament drives to an improvement of the conditions of life, on the condition of making a success of the process of the conversion of military plants.

Considering the importance of the differences between the members of the Association, EPS joins however a will for an exchange of economy of conflicts and domination, in favour of a peaceful and welfare economy. It also proposes a general scientific debate in order to develop at the same time the idea of the inescapability of the war and the cumulative process of arms race leading 
inexorably to the armed conflicts. At first, a world war would have dreadful consequences on the humanity. In these conditions, it is certainly necessary to look for the theoretical causes of the conflicts. Second, the arms race constitutes an act against economic values, when it does not supply an improvement of the need of security. Finally, the search for peace also can be improved by the refusal of the dominations, excessive disparities and the world poverty. These situations are mainly of economic nature.

Some analyses about war, conflicts and economy

For Paul Dunne and Fanny Coulomb, the economics of peace war and international security is a huge wide-ranging topic that is difficult to summarize. Peace, war and international security are scientific areas in which economists are often absent. The supposed imperialism of economics of the social science $»$ is reversed. After outlining some general perspectives on international security, the authors propose a schematic presentation of the main theoretical approaches. Then, they develop neoclassical theories, Keynesian and institutional, Marxist, and monopoly capital of the economics of security, introducing an economic debate on the economic causes of war and peace.

For Ron Smith and Jacques Fontanel, security has a large variety of meanings and situations. If during the Cold War the major problem of the international security was the threat of a nuclear war, now the main questions are global warming, famines and terrorism. Globalisation is not new. Nations remain very important. Then, analysts must take account of the internal determinants of military expenditures. Moreover, industrial and political interests, inter-service rivalry and a variety of bureaucratic forces are often a threat for peace. There are international institutions, but their effectiveness depends on the willingness of the nation states to support their activities. "Today, the military actions are privileged, neither but nor for predation objectives. With the economic international dependence, the superpowers understand that without the threat of the use of their weapons, they are dependent of all states that are in situation of force for a special strategic production or resources".

For Michael Intriligator and Fanny Coulomb, the complexity of the problem of global security is growing. The global security is the absence of threats to the vital interests of the planet. Then, the idea of security must extend well beyond its traditional military dimension. Now is an opportune time to build global consensus on these issues. Human security concerns freedom from pervasive threats rights, safety or lives of human beings, involving both fights against violent threats, such as wars, violations of human rights or terrorism and violent crime" and safety from 
non-violent threats, such as environmental degradation, drugs, infectious diseases and natural disasters. The authors propose two main actions in order to secure the world system: the restructuring of the UN system, with new international roles attached to international agencies, NGOs or multinational corporations, and an investment on 50 Manhattan Projects with the resort of science in dealing with Global Threats.

For Fanny Coulomb and Jacques Fontanel, as the military and strategic needs are different from those the past military needs for international security, the new armament demand are also realized on the basis of some "disarmament process" for obsolescent armament productions. The reorganization of industries of armament was initially presented as a factor of "creative destruction". From a cultural point of view, the military sector is expressed mainly in the field of the high technology, but the "priority defence" that it exerts is likely to delay or modify technological progress. It privileges some specific technologies, which influence the civil sector. It is possible, in spite of rigidities and the "practice effects", to apply the military research and development to its counterpart civil. States always used the military sector to set up their industrial policy. Within the framework of the globalization, the United States made a success of the conversion of their military effort, while remaining the great world economic and military power. For the United States, the opening of the economic borders is a factor of world peace. The paradigm of "laissez-faire" reminds dominant and, as underlines in the liberal thought, it is a factor of peace and disarmament. This hegemony is likely, in the long term, to pose problem.

For Keith Hartley, Renaud Bellais ad Jean-Paul Hébert, the European defence industry has been considerably transformed since the 1980s: privatization of stateowned firms, national consolidation, Europeanization of the industrial base. This restructuring process reflects political changes but it also, and mainly, results from major economic trends in the production of defence systems: the rising cost of $\mathrm{R} \& \mathrm{D}$, scale and learning effects, imperfections of supply and demand side. Beyond the adaptations already engaged by both states and firms, there is a growing contradiction between the challenges of restructuring the European defence industry and the economic trends from which firms (and nation states) cannot escape. Current stalemates result mainly from the fragmentation of the European defence equipment market. It is necessary to go beyond the current limits of both market size and the industrial base to overcome these constraints. If cooperative programmes provide gains from scale and learning economies, they have many limits. It is only by creating a single defence market that European states can expect to keep the production of defence systems affordable. Moreover a convergence on the demand side constitutes the very condition for the creation of a competitive European industry. Beyond capitalistic consolidation, firms must be able to 
integrate and restructure their capabilities at the right level, the European one. By its achievements as well as its limits, the evolution of the European defence industry underlines the specific features of this industry. It can help understand both the transformations of the defence industry worldwide and the possible transformations that could take place in Europe, especially in order to preserve a local defence industrial base.

For Alexander Karlik, Igor Maximtsev, Jean-Paul Hébert et Louis-Marie Clouet, the national defense industry is closely connected with the potential military threat. They analyze three main characteristics: the development of dies as the reaction for external threats, the commercial pragmatism in Russian arms export policy and the evolution of the Russian aeronautic industry. After a definition of Russian DefenceIndustrial establishment and its evolution, they explain the increase of Russian military expenditures. The commercial arms export policy is pragmatic, selling to "anti-American states", in a successful combination of debt reduction, energy and arms deals. Russia has to cope with other new competitors for technology lowintensive products. Russian authorities regularly criticize East-European countries for producing Soviet-designed armaments without patent. Finally, there are a radical concentration, a restoration process on the external markets, and a development of links with Western countries of the Russian aviation industry.

Jacques Fontanel and Ivan Samson consider the explanatory factors of US military expenditures. What are the main explaining factors of the constant increase in the American military expenditures? What is the share of internal determinants in the process of resource allocation to the military budget? They point out the arms race mechanism, the emergence of new threats, the existence if a national armament industry, the importance of the national military R\&D and the growth of the State budget.

For Michael Ward and Peter D. Hoff, many empirical trade models assume that the flows of goods among countries is independent, that goods and services flowing from France to China are independent of goods and services flowing from France to Japan, for example. Despite the obvious mistake in this assumption, gravity models of international commerce tend to assume that the world is inhabited by independent economic actors. This analysis provides a new perspective to describe and detail the complex patterns of actual geo-economics interdependence in the context of the well-known gravity model if international commerce. It also explicates geographical and geopolitical factors that influence these interdependencies. Results from contemporary data show strong out of sample forecasting ability.

For Mike Intriligator and Steven Coissard, the new era of terrorism came within the scope of geopolitical and economical issues since the collapse of the USSR. Economic factors could not explain this mutation; since 1990's the motives of 
terrorists refer to religion and fundamentalism. Terrorism, structured around political claims, is gone. Now, attacks could hit anyone, anywhere, anytime, without explicit demands. With such new form, traditional concepts of war or terrorism were smashed to smithereens. The aim of the paper is to analyze terrorism as an economic phenomenon, in order to understand and control it. Such an economic approach is complementary to other approaches that treat terrorism in terms of law and law enforcement, psychology, international relations, military studies. The paper will examine terrorism towards two main actors, terrorists and antiterrorists, how they are using medias, collaboration, intelligence or innovation.

Nadège Sheehan discusses the characteristics of peacekeeping operations. Member States are mainly motivated to contribute according to their national interests, because UN missions generate joint products and contributor-specific benefits. However, these operations are responsible for the UN financial crisis. As UN peacekeeping budgets grow up, the members of United Nations Organization show their reluctance to pay contributors of personnel and equipments. Then, they affect future missions, especially as deployments of forces depend on voluntary contributions by governments. The author analyzes some potential deployment options for producing peacekeeping.

For Liliane Bensahel, Steven Coissard and Claske Dijkema, as a result of the first world conferences on the status of women held in Mexico in 1975 to Nairobi in 1985 (The U.N. decade for women), women issues were taken into account or mainstreamed in all programmes. Nevertheless, in the gender analyze there are both key text. First was produced at the Beijing Conference in 1995, second was the United Nations Security Council Resolution 1325. This paper presents the slow development of gender approach in institutional responses to conflict. We review, 7 years after the UN resolution 1325 and the Beijing +5 conference, advances in term of women representation, justice, recognition of women civic and citizen rights,

For Jacques Fontanel and Albane Geslin, since 1990s, there is a new system of security, with three fundamental changes, partially managed by the United Nations system. First, with the process of the globalization, the protection of the ecosystems is highlighted. Second, human rights and protection of minorities suppose an agreement of universal values in the world order, with the development of the process of democratization. Thirdly, with the creation of international criminal tribunals and court, the political leaders became responsible individually of the crimes of their regimes. In this context, the political economy of the humanitarian supposes two dimensions. First, it makes reference to the "voluntary" role of the political system for the satisfaction of the human needs. It supposes a collective and peaceful action, engaged by States, international organizations or nongovernmental organizations, to reduce the poverty, improve the conditions of life and insure the dignity and the security of all people. Second, the political economy 
refers to the humanitarian intervention, as an action of force organized at the international level by $\mathrm{UN}$, regional organizations or States, to fight against systematic violations of the humanitarian right on the territory of another State. Third, if the economic development of Nations is a fundamental factor of the international security, the defence of a country is a condition of its development.

For Carlos Seiglie and Steven Coissard, economic intelligence is an important factor in the modern life. "Know your enemy" is a basic precept of warfare and it emphasizes the key role of intelligence. The American system of economic intelligence is the best in the world even if with the creation of the U.S. Department of Homeland Security, which is dysfunctional and has been largely ineffective, it concluded to the disastrous response to hurricane Katrina. However, organized around a private public partnership and public structures mobilization, the U.S. system of intelligence has no competitor. The issues of this paper is to understand why the American system is the best and how economic intelligence is impacting on national security and are increasing of the country's future income.

For Jurgen Brauer, the links between and among international security, economic development, and a sustainable ecosystem, particularly with respect to how international organizations have dealt with these subject matters. The paper finds that for the most part, work done emphasizes bilateral unidirectional causality, for example, from disarmament to development, and argues not only that bilateral reverse causalities can often be established but that the topics of development, sustainability, and security need to be dealt with en bloc, in trilateral fashion. Moreover, the main practical issue does not lie primarily with proper amounts of funding, but rather with the quality of domestic and global public sector decisionmaking.

\section{Bibliography}

Bensahel, L., Coissard, S., Dijkema, D. (2008), The gender approach in institutional responses to conflict, in War, Peace and security, (Fontanel, J, Chatterji, M, Eds.) Vol 6. Emerald, London.

Brauer, J. (2008), International security and sustainable development; in War, Peace and security, (Fontanel, J, Chatterji, M, Eds.) Vol 6. Emerald, London.

Dunne, P., Coulomb, F. (2008), Peace, war and international security. Economic theories, in War, Peace and security, (Fontanel, J, Chatterji, M, Eds.) Vol 6. Emerald, London.

Fontanel, J., Chatterji, M. (2008) War, Peace and security, Vol 6. Emerald, London. 
Fontanel, J. (2008), The economic reorganization of the military sector at the beginning of the twenty-first century, in War, Peace and security, (Fontanel, J, Chatterji, M, Eds.) Vol 6. Emerald, London.

Fontanel, J., Geslin, A. (2008), Political economy of the humanitarian actions, in War, Peace and security, (Fontanel, J, Chatterji, M, Eds.) Vol 6. Emerald, London.

Fontanel, J., Samson, I. (2008), The determinants of military expenditures, in War, Peace and security, (Fontanel, J, Chatterji, M, Eds.) Vol 6. Emerald, London.

Foucault, M. (2008), Does European defence burden-sharing matter ? in War, Peace and security, (Fontanel, J, Chatterji, M, Eds.) Vol 6. Emerald, London.

Hartley, K., Bellais, R., Hébertts, J-P. '2008), The evolution and future of European Defence firms, in War, Peace and security, (Fontanel, J, Chatterji, M, Eds.) Vol 6. Emerald, London.

Intriligator, M.D., Coulomb, F. (2008), Global security and human security, in War, Peace and security, (Fontanel, J, Chatterji, M, Eds.) Vol 6. Emerald, London.

Karlik, A. Maximtsev, I., Hébert, J-P., Clouet, P-M. (2008) Defence-industrial establishment of Russia, in War, Peace and security, (Fontanel, J, Chatterji, M, Eds.) Vol 6. Emerald, London.

Luterbacher, U., Nottlöf C. (2008), Securing the environment and securing states, in War, Peace and security, (Fontanel, J, Chatterji, M, Eds.) Vol 6. Emerald, London.

Mazrui, A. (2008), Race versus culture in politics and war: implications for Africa, in War, Peace and security, (Fontanel, J, Chatterji, M, Eds.) Vol 6. Emerald, London.

Seiglie, C., Coissard, S., Echinard, Y. (2008), Economic intelligence and national security, in War, Peace and security, (Fontanel, J, Chatterji, M, Eds.) Vol 6. Emerald, London.

Sheehan, N. (2008), Economics of the peacekeeping operations, in War, Peace and security, (Fontanel, J, Chatterji, M, Eds.) Vol 6. Emerald, London.

Smith, R., Fontanel, J. (2008), International security, defence economics and the powers of Nations, in War, Peace and security, (Fontanel, J, Chatterji, M, Eds.) Vol 6. Emerald, London.

Ward, M., Hoff, P.D. (2008), Analyzing dependencies in geo-economics and geo-politics, in War, Peace and security, (Fontanel, J, Chatterji, M, Eds.) Vol 6. Emerald, London. 